\title{
The dimensions of God in selected poems of Kareem Dashti
}

\section{Hawzhin Sliwa Essa ${ }^{1}$,}

Received: February 15, 2016 Reviewed: March 25, 2016 Accepted: April 16, 2016

\begin{abstract}
This study, entitled (The Dimensions of God) deals with one of the Kareem Dashti's poems that presents a bunch of the above mentioned dimensions which reflect the God's existence. The writer has quoted similar texts from other Kurdish poets to enrich his study and to reinforce the theme which he skillfully explains. All the selected quotations here serve the chief thought of the subject. The explanation of the text is clarified by some meaningful diagrams. The aesthetics of the text and its surface structure \& deep structure are accurately analyzed as well.
\end{abstract}

Keywords: Kurdish literature, modern literature, Kareem Dashti, poetry, dimensions of God.

Recommended citation:

Essa, H. S.. (2016). The dimensions of God in selected poems of Kareem Dashti. International Journal of Kurdish Studies 2 (2), 24 - 36.

${ }^{1}$ Corresponding Author: Dr., hawzhen.slewa@koyauniversity.org 


$$
\text { زانكوّى كوّيه- فاكهلّتى وهروهرده- باهشى كوردى }
$$

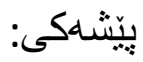

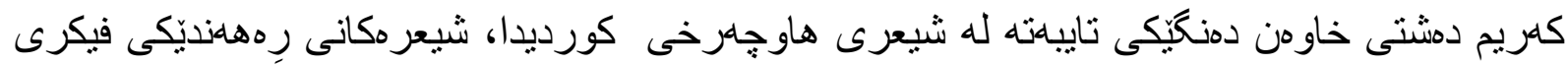

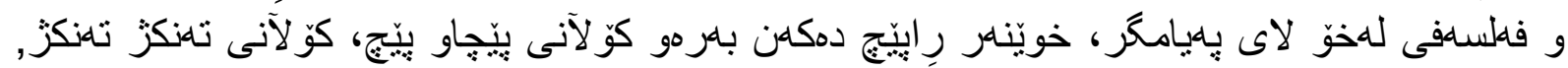

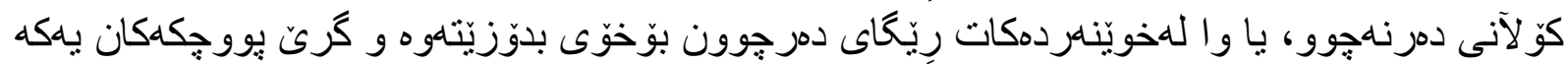

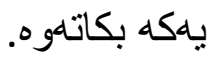

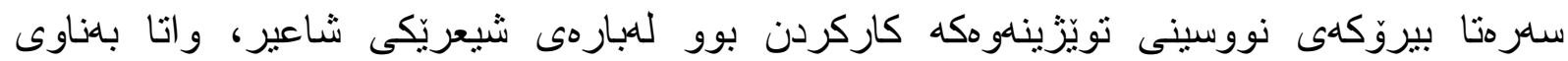

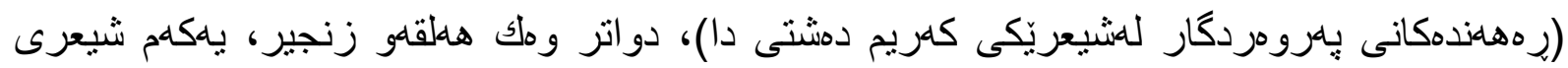

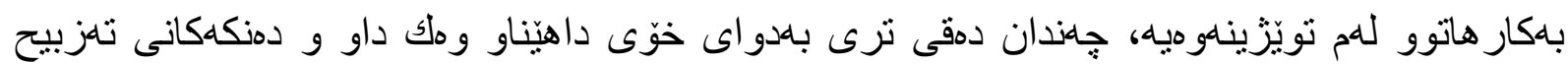

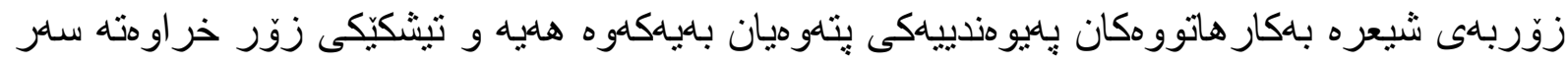

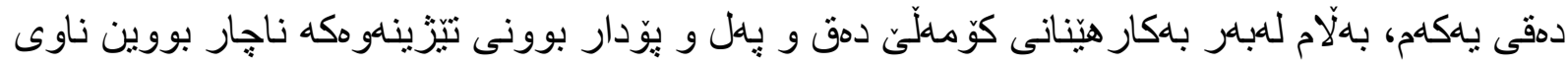

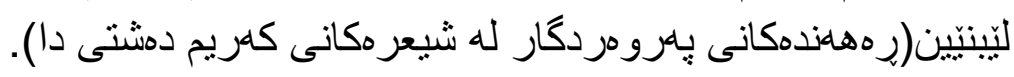

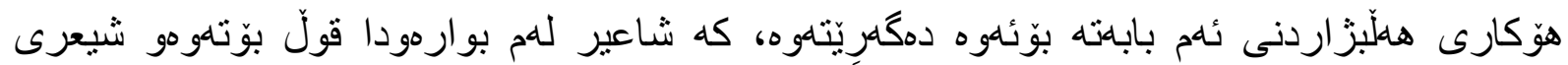

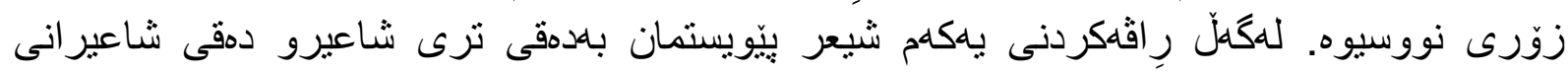

$$
\text { تر هلبوو. }
$$

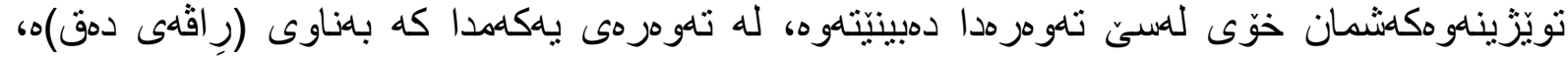

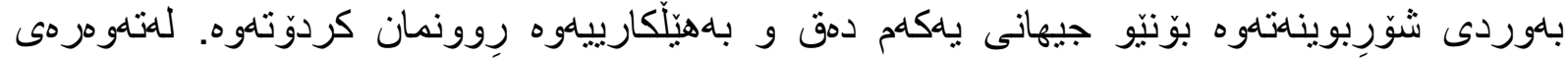

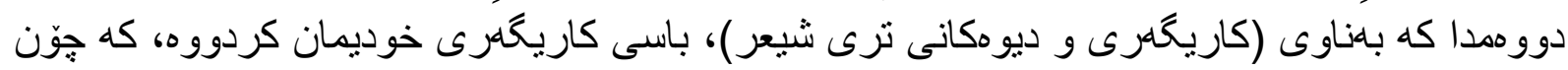

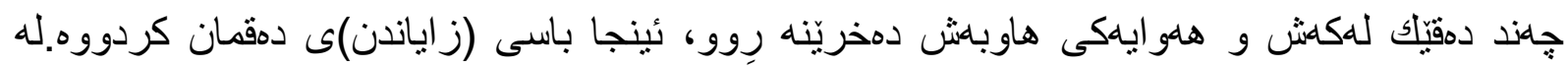

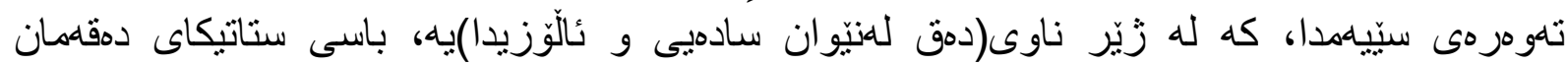

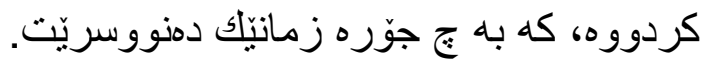

$$
\begin{aligned}
& \text { تاهو هرمى يهكدم: رير اقدى دمق:- } \\
& \text { هلندي جار لهنيّوخهو ندا خلون ئهبينم } \\
& \text { لـنيّيو شووشهى نأودا بيابان ئهبينم } \\
& \text { بوّ لووتكه ئهجم ئمكَم بابنار } \\
& \text { لهنيّو دهريادا تهرمى شهيوّل و نهور هسى كهنار } \\
& \text { لهنيّو تابلوّدا مدركَى رِمنحككان } \\
& \text { هلموو شتئ للمهدارى خوّى ترازاوه } \\
& \text { تهنها توّ نهبيت وهك شاموقى ئهزمل }
\end{aligned}
$$




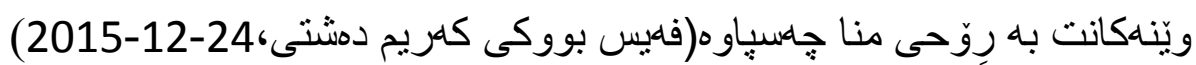

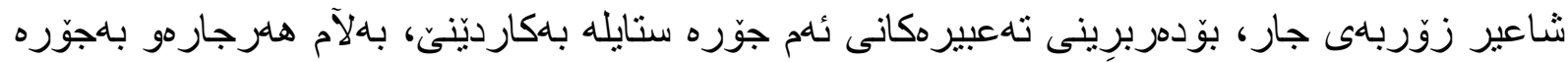

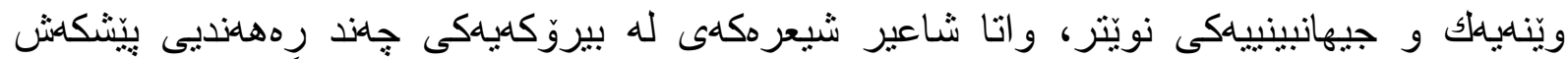

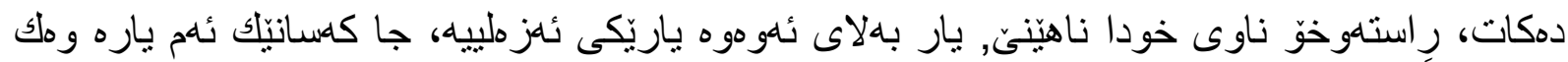

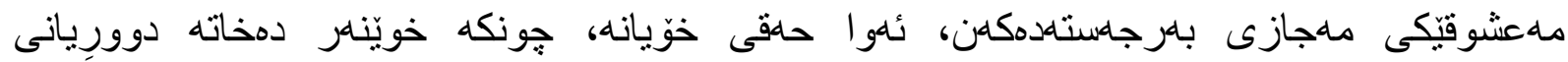

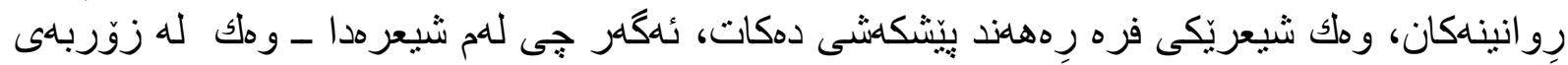

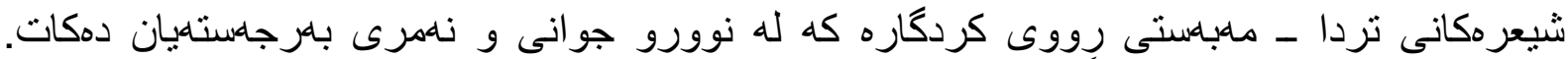

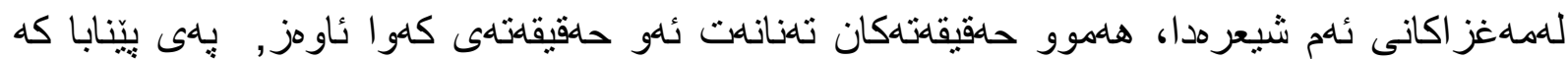

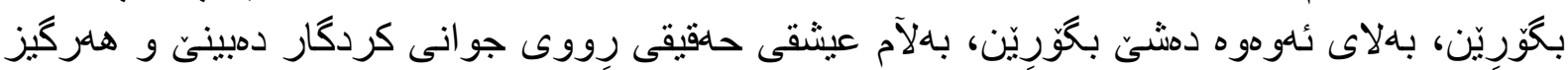

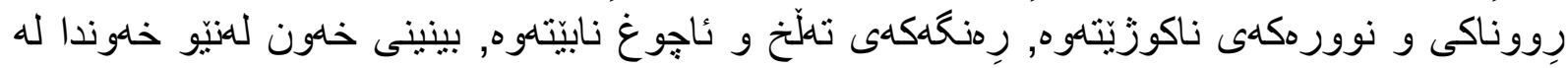

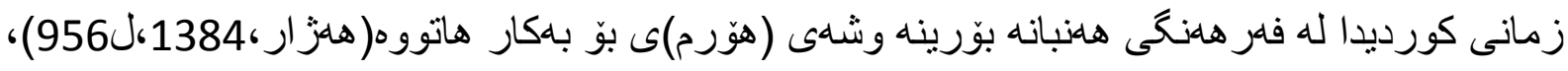

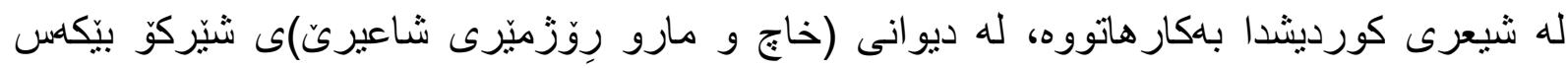
واهاتووه:

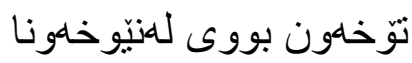
توّ بياو انى قهر هداغى و ولك نهرِ امسين... وهك هلريّس سنع تووكن و وهك دمربهندى باسلمرِه

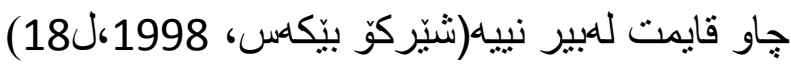

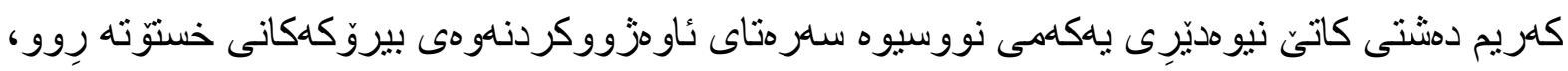

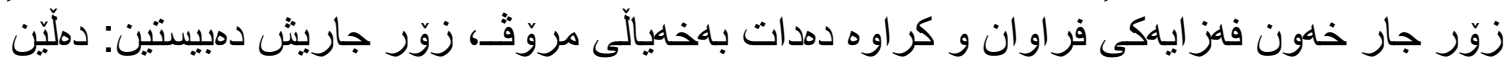

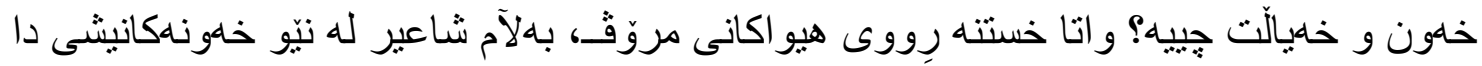

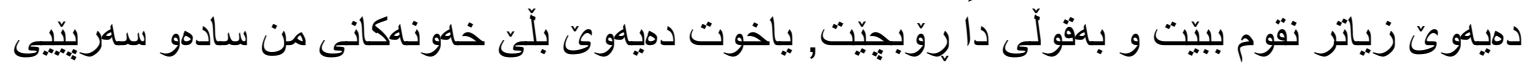

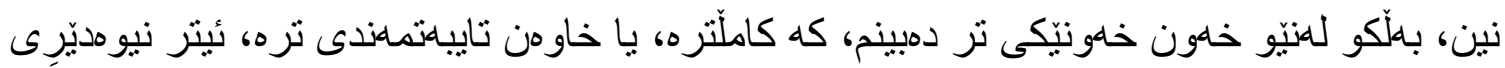

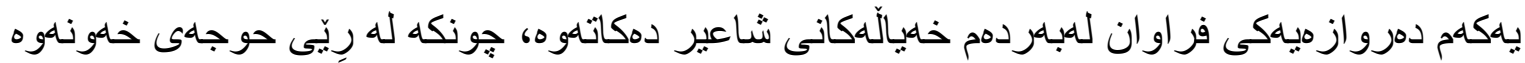

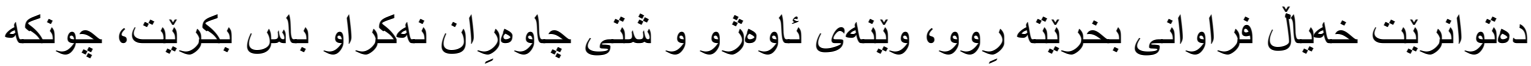

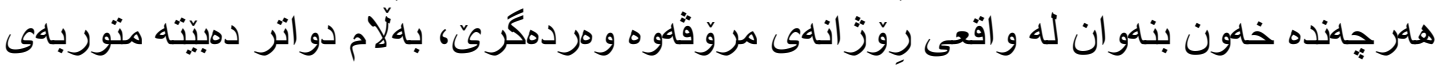

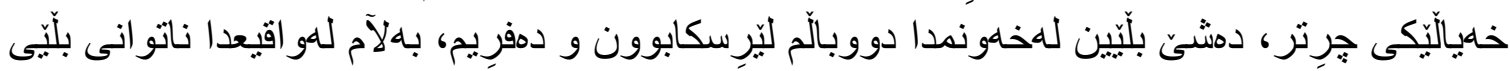

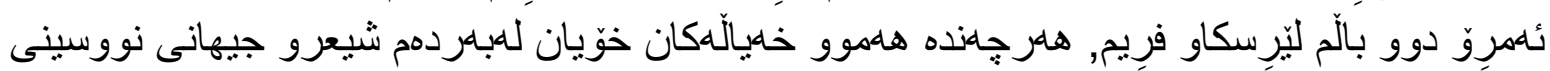

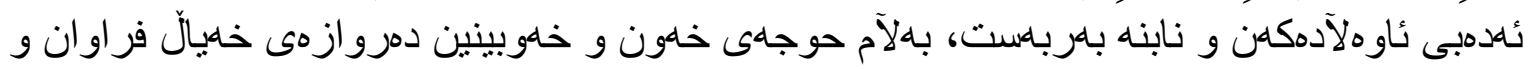

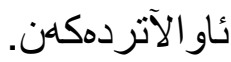




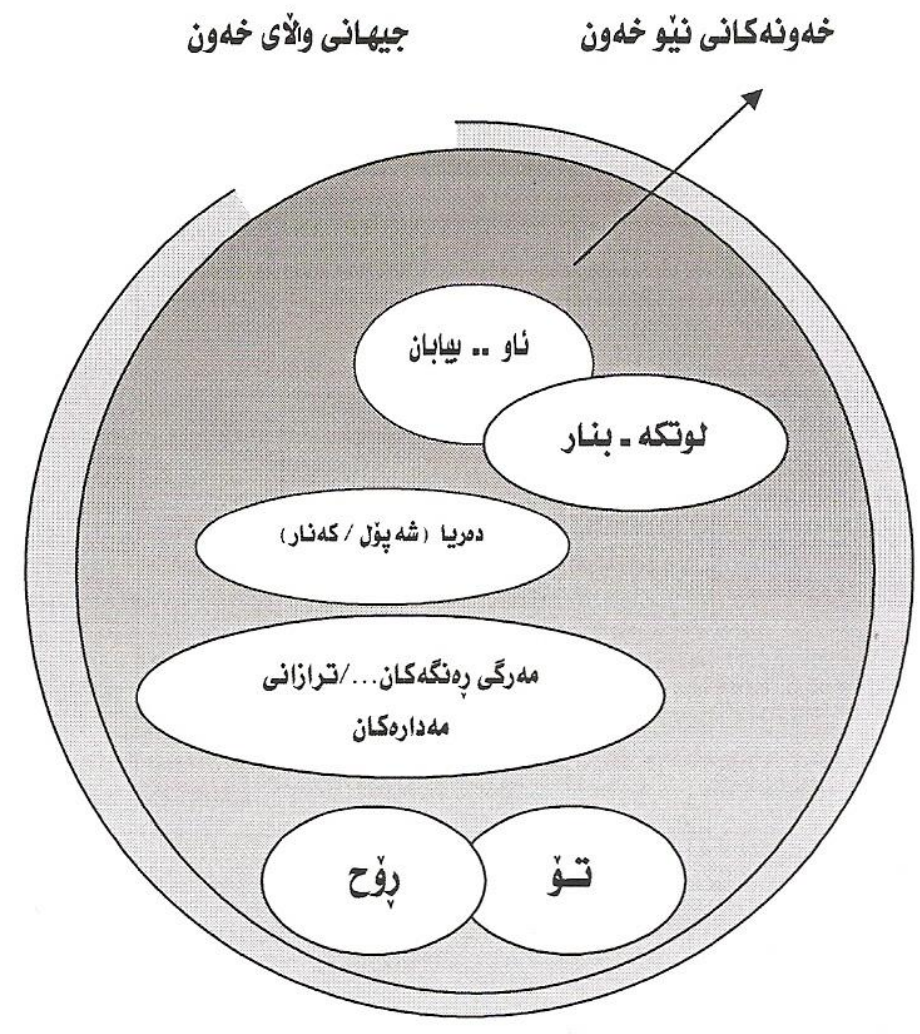

هيّكاريى خهونبينى شاعير لهم دوقهدا

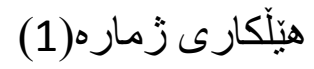

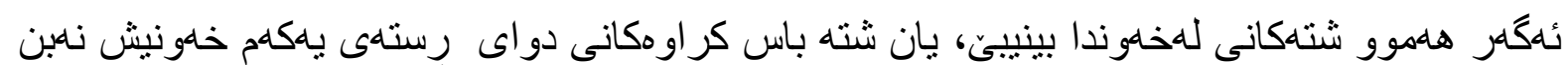

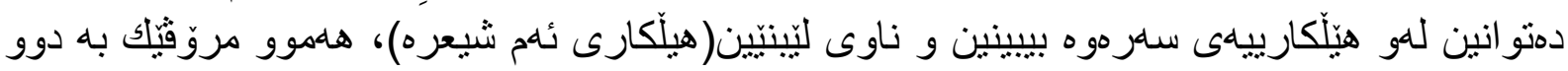

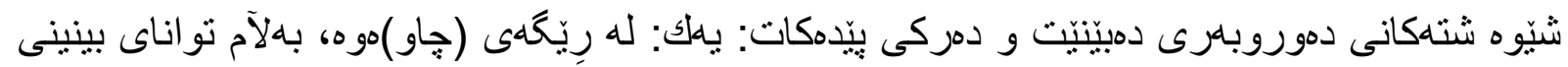

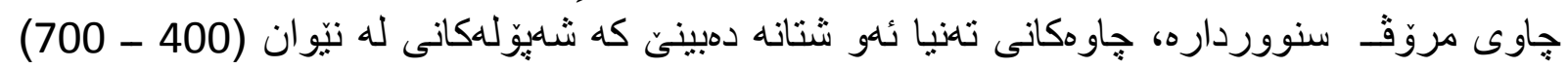

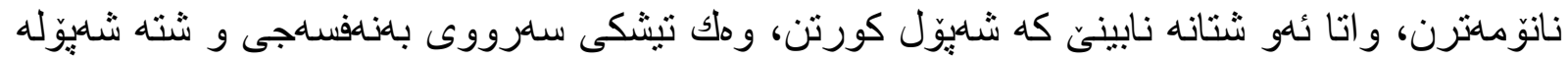

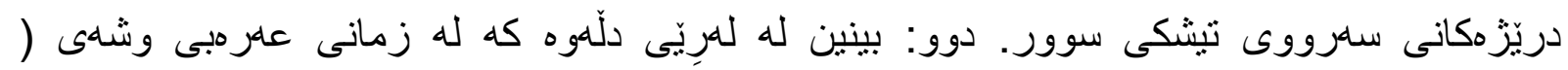

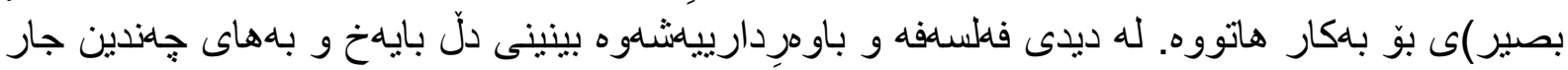

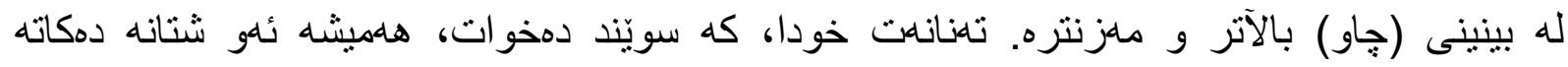

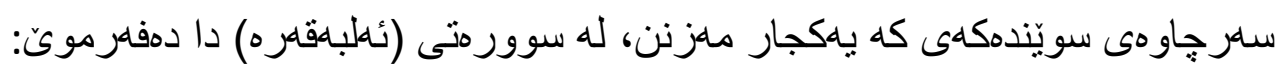

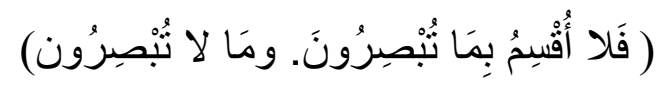

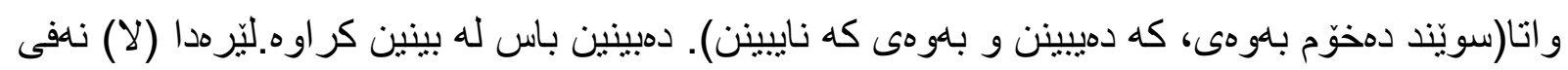

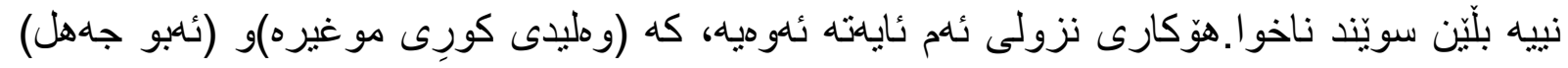

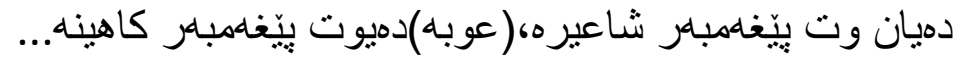

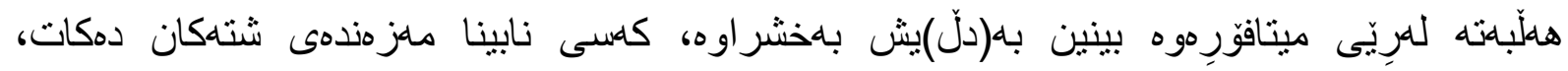

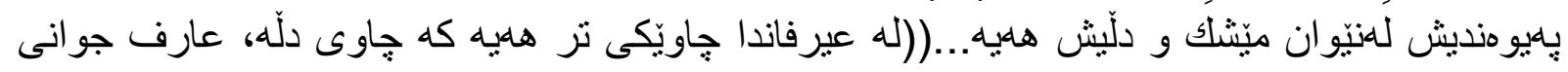




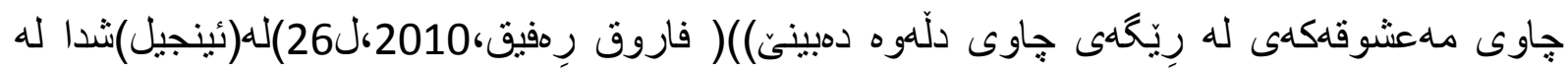

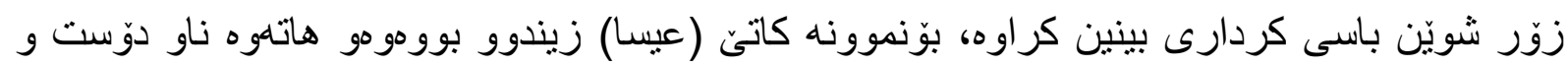

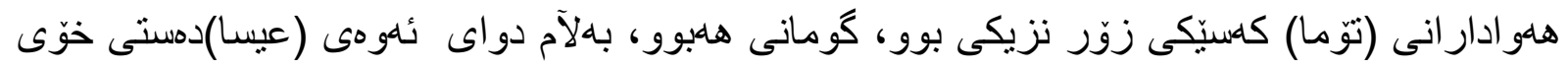

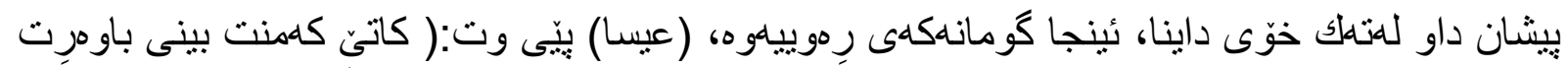

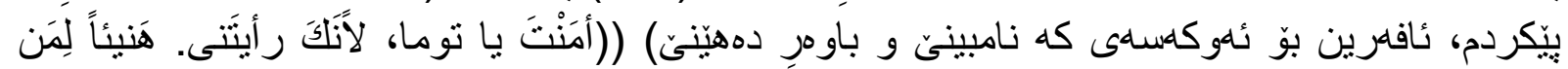

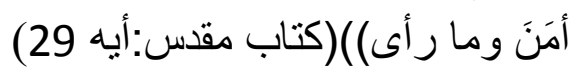

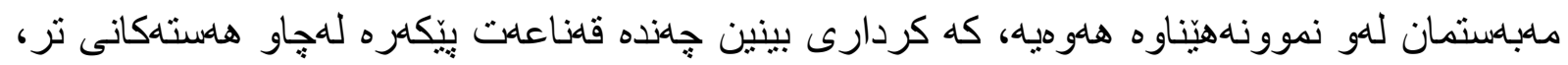

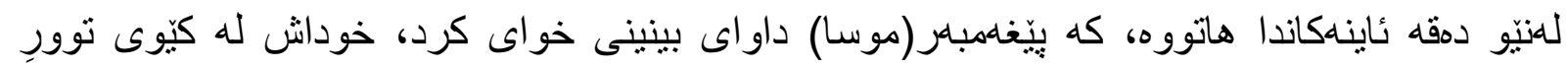

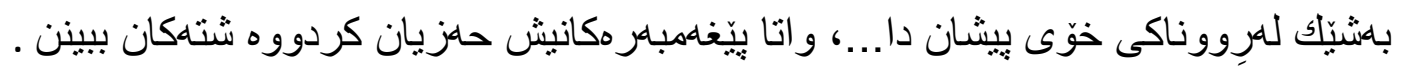

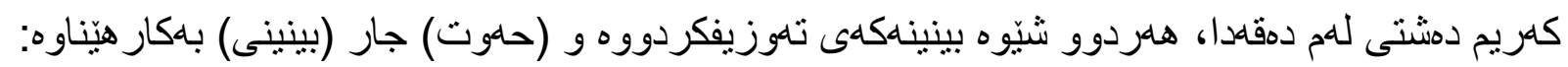

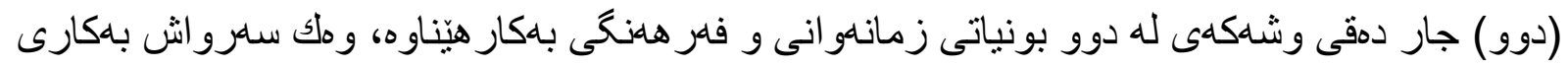
هيناون:

هلهنديّ جار له نيّو خهوندا خلون ئهبينم له نيّو شـوشسهى ئاودا بيابان ئدبينم

(0) جاريش (بينينى له ريّى دلّوه) ويَناكردووه: بينينى

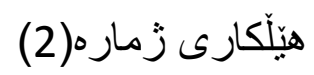

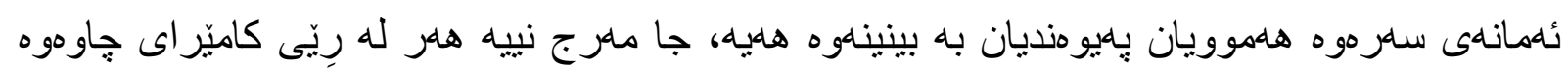

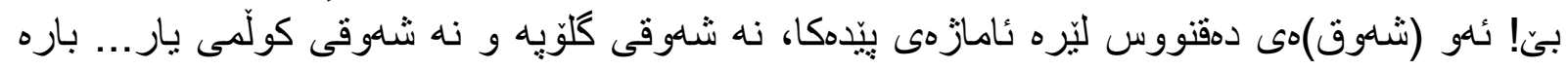

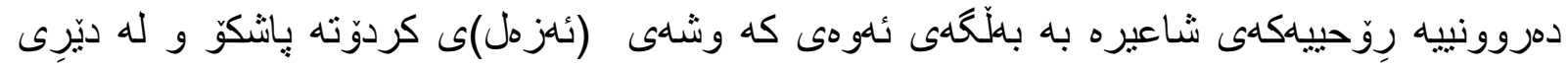
دو اتريشدا دملِّى:

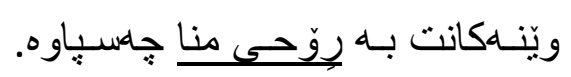

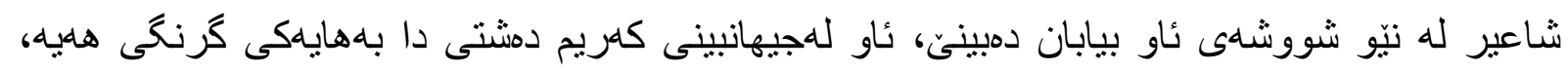

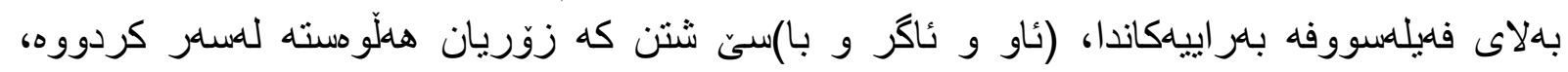




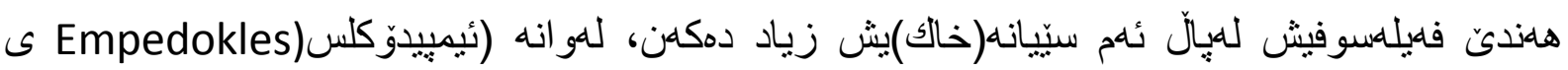

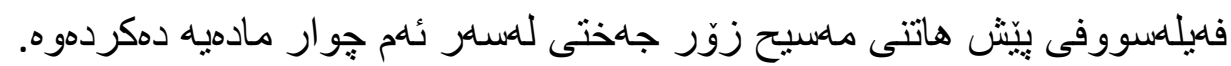

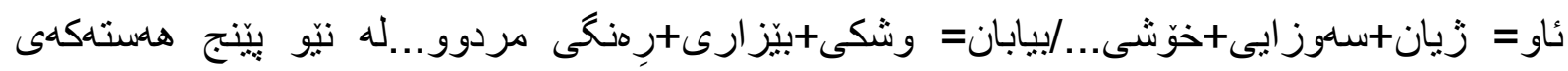

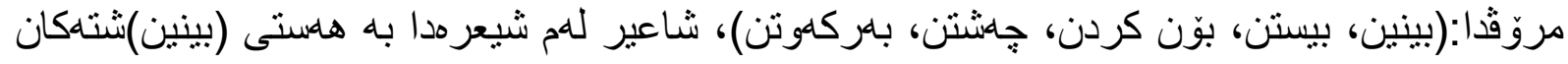

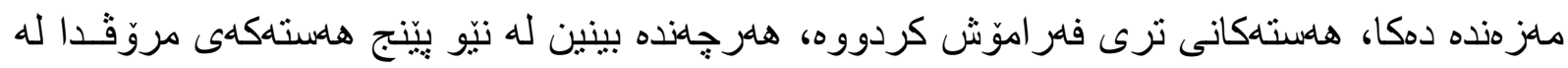

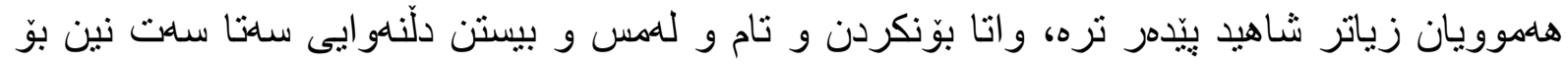

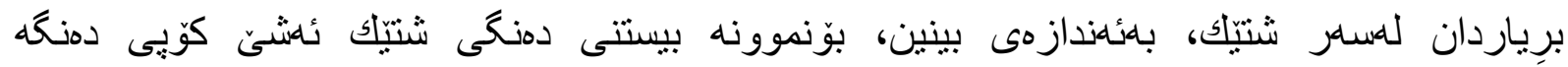

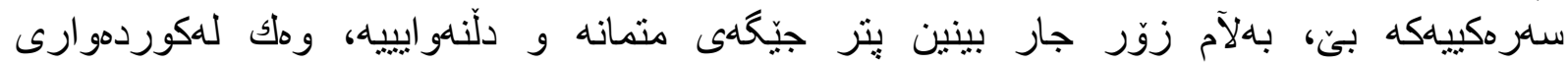

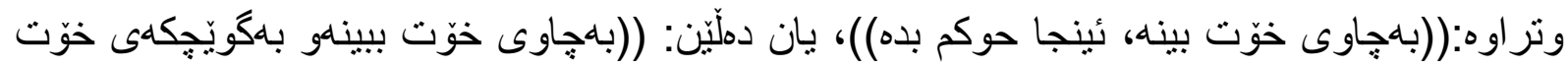

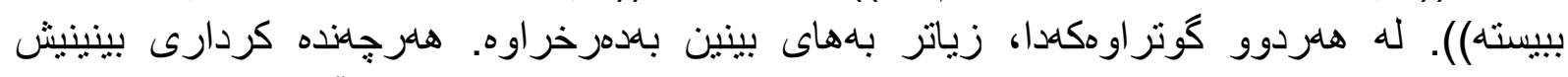

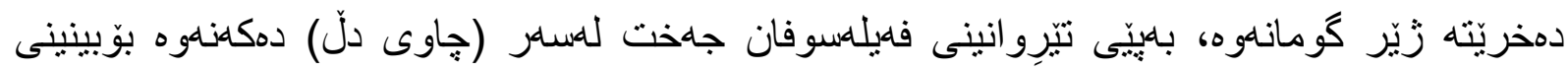

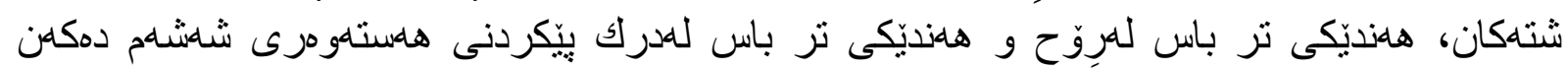

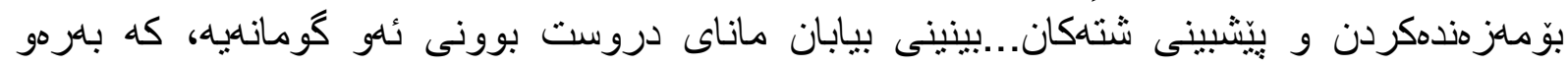

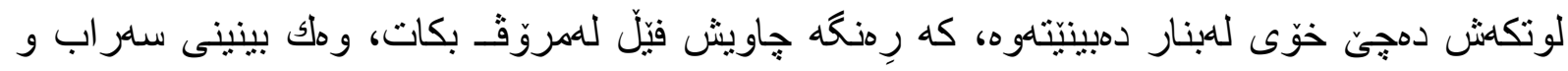

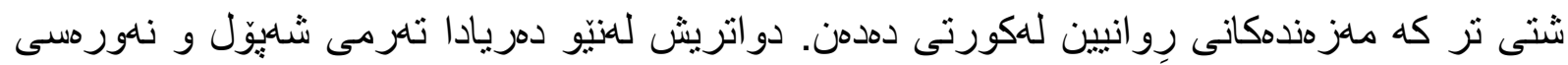

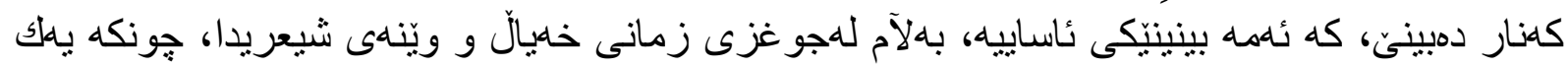

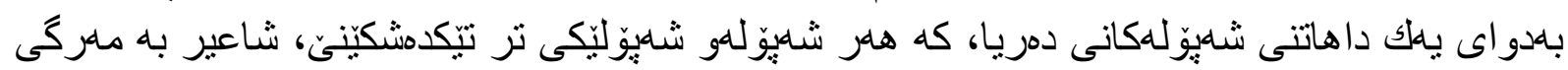

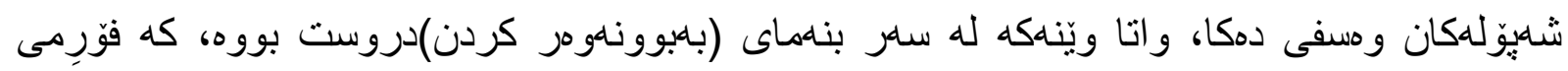

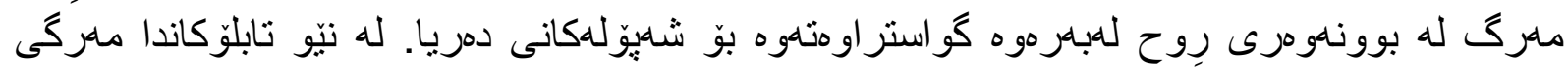

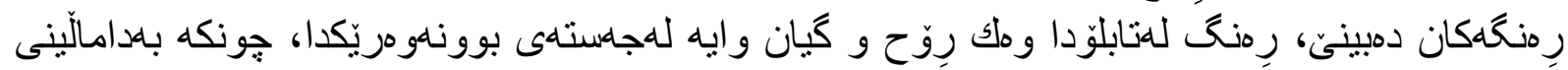

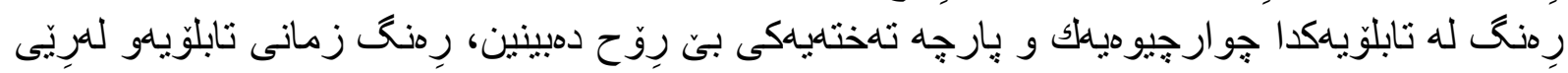

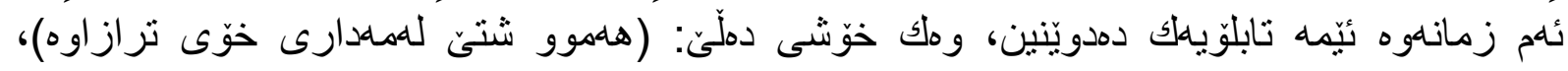

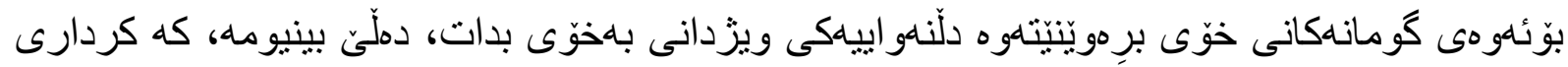

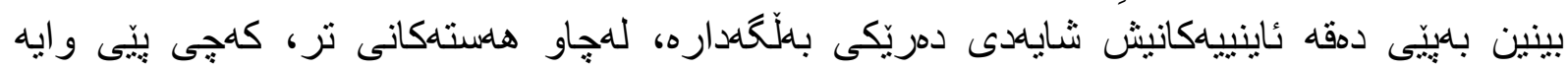

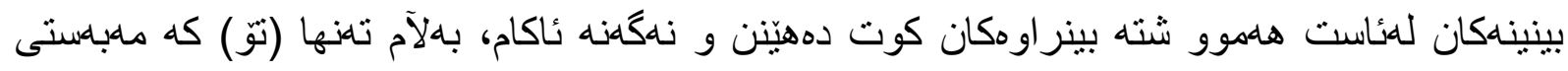

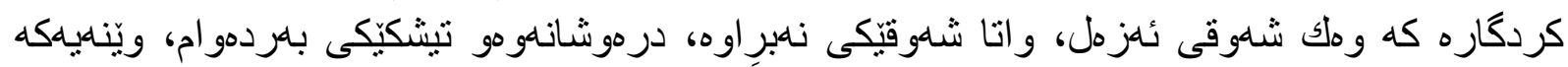

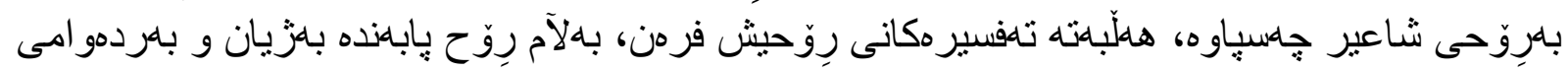

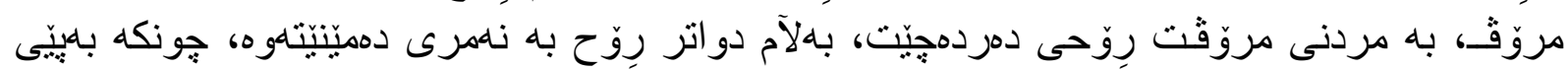

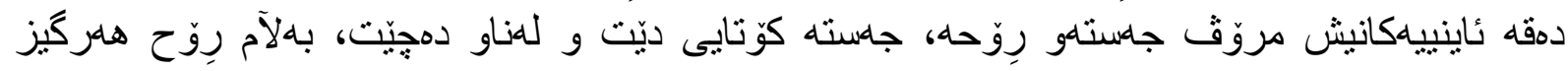

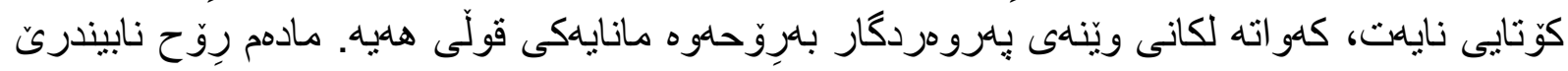

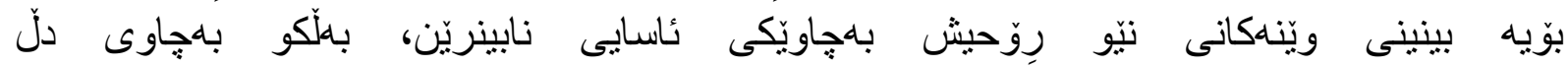

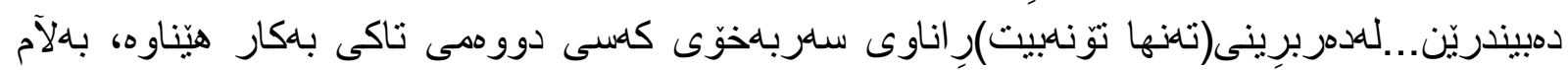

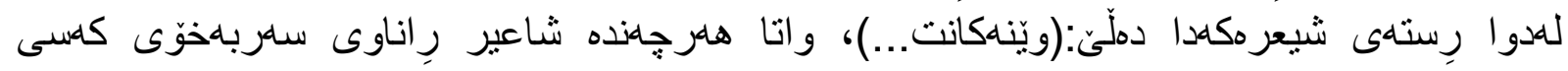

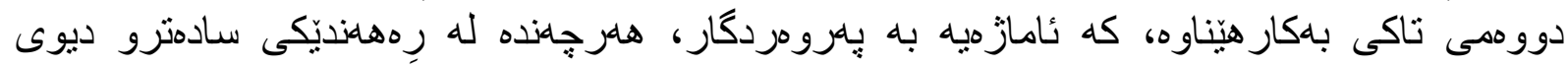

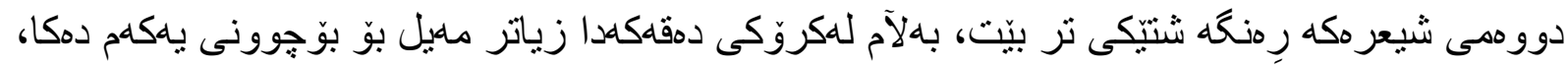

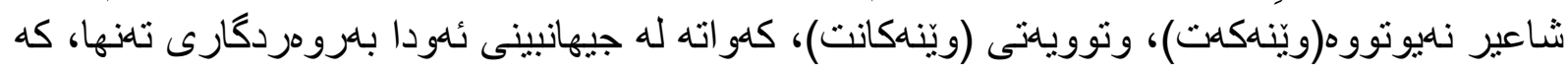

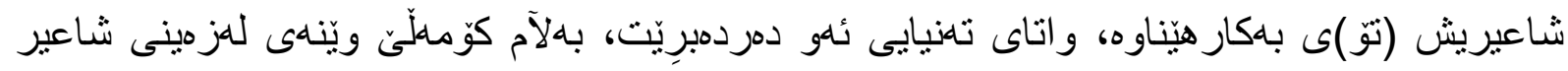




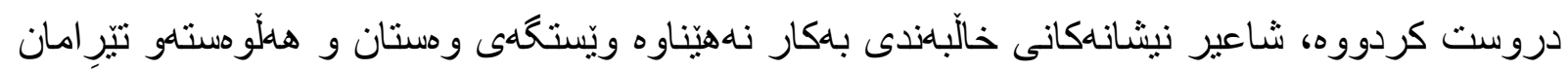

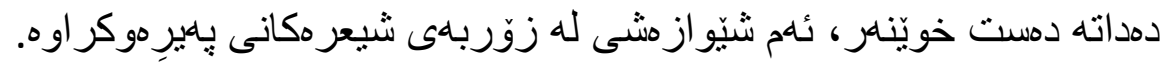

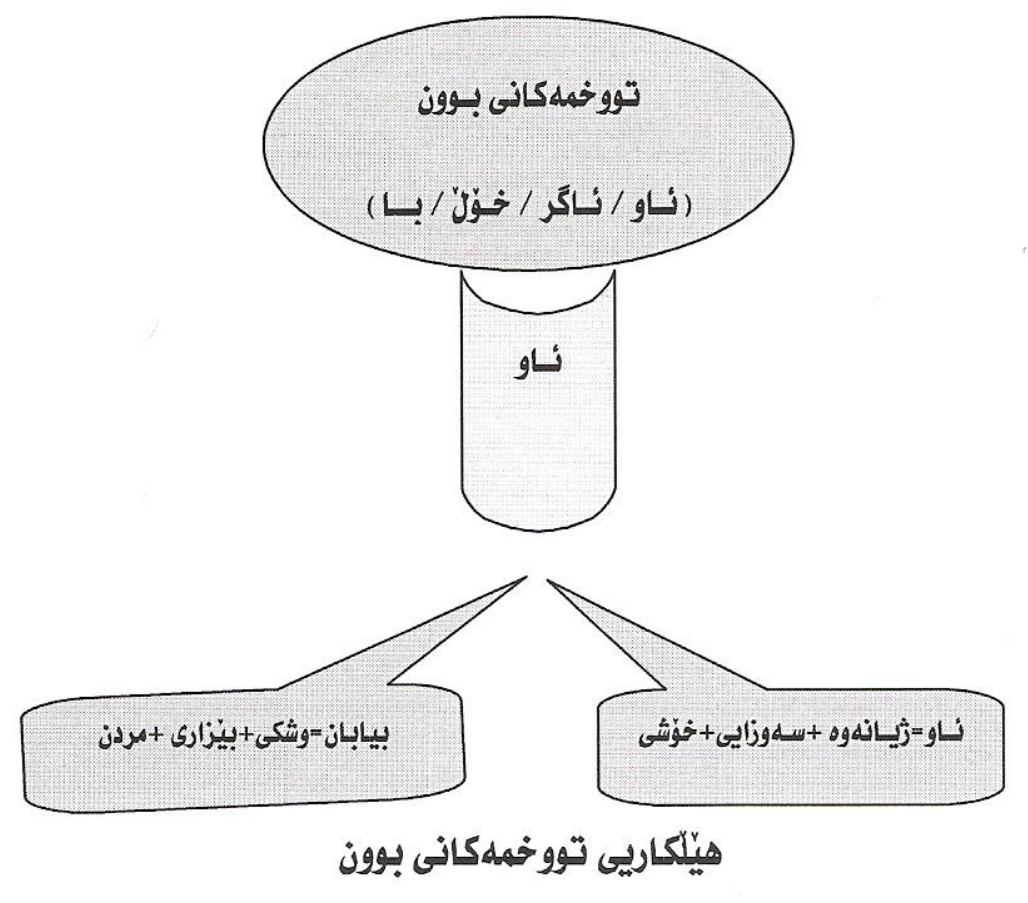

هينّكارى زمار (3) (1) (1)

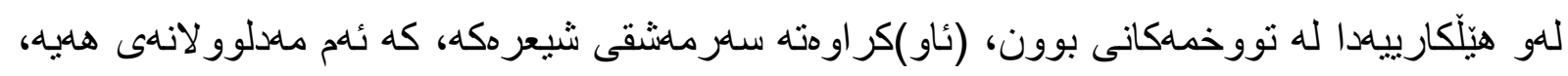

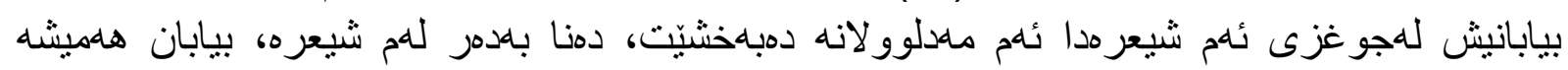

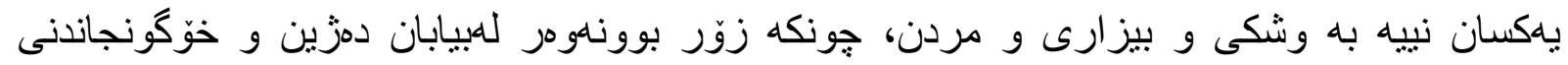

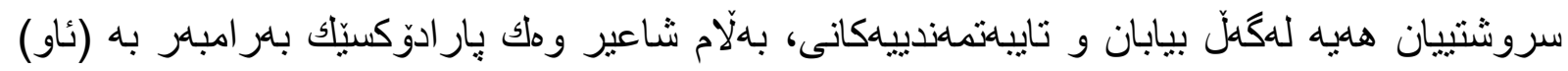
ئسو مهدلوو لانهى كمر ككه.

له شيعريكى تردا بهرِوونى ئهم توخمانه ديارن نئهو نتا له شيعرى(خوّ نهبوون)دا، و اهاتووه: تلهمهشا جهاند ساهيره

من بادو اى ئهوينت ومكو يوشى بهربا ياهرش و بلآوى هلموو سارزموى كر اوم ومكو ئاو رِزَاومه ناو هلموو بنارى وهكو كرِ له هلموو خهميّك داكيرساوم كه تّو واى للهناخما

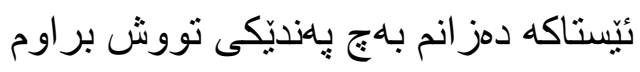




$$
\text { من تازه بز انم هى خوّم نيم }
$$

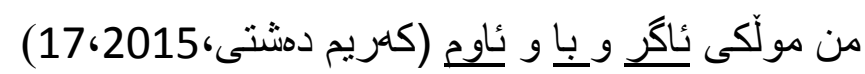
تاوهرهى دووهم: كاريخمرى و ديويَوهكانى ترى شيعر:

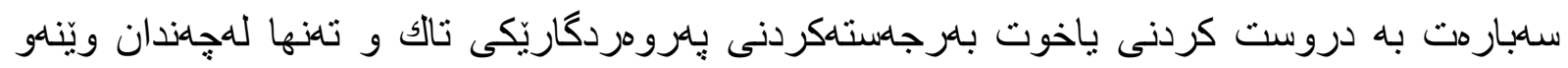

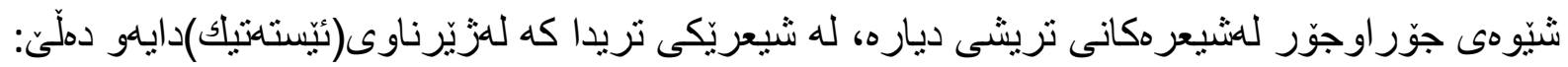

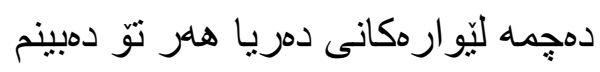
دمجمه دارستان هلرتّ دمبينم دمجماموه رِابردوو دمجماوه ئاينده هلر توّ دهبينم توّ يهكسان بوويت لهكَّل كهون (كهريم دمشتى، 2012، ل14) له جهندان شيعرى تردا كاريحهرى خودى يِّو هدياره له شيعرى(خيّر ا خيّر ا بودو اوه)دهلّي:

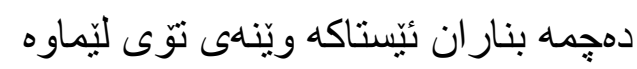
دمجماهوه ناو لوولهى شمشالان

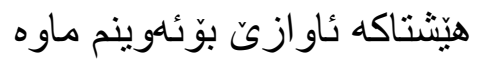

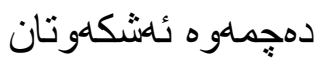

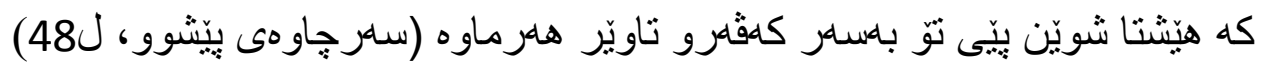

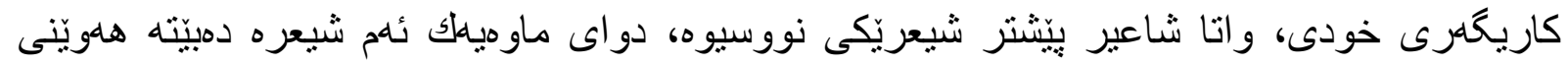

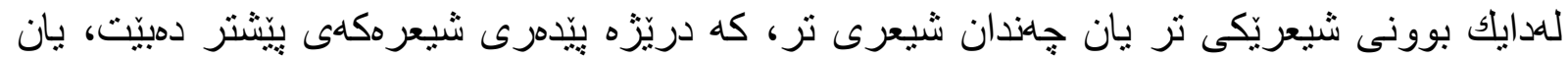

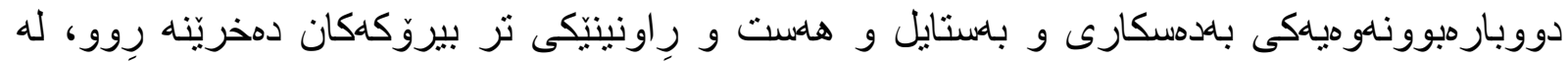

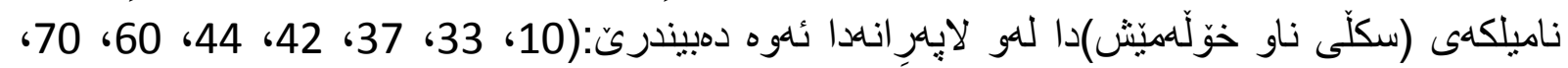

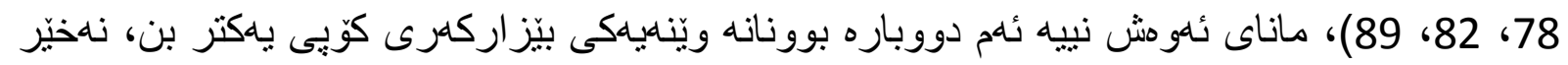

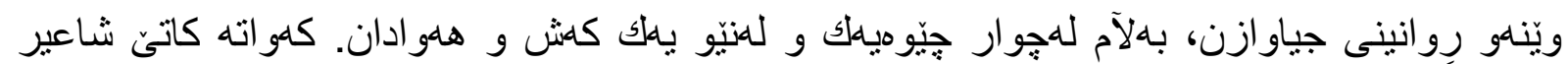

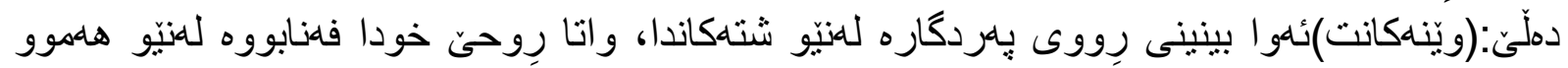

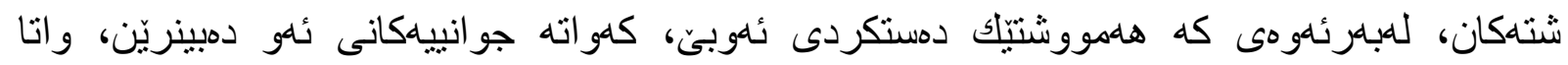

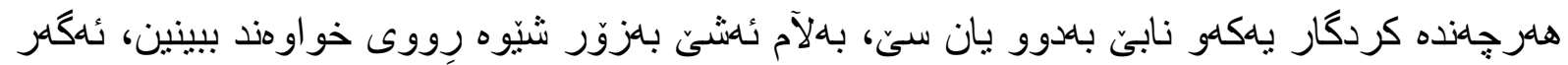

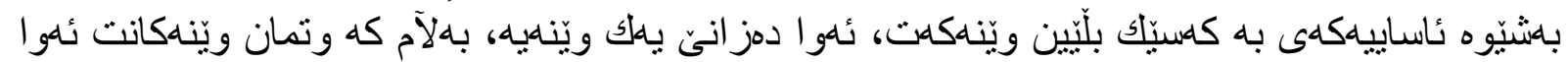

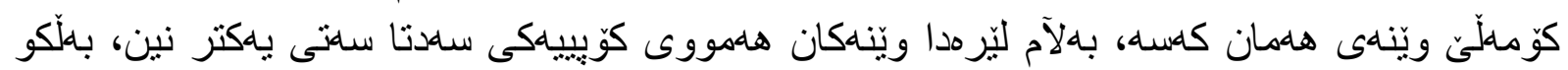

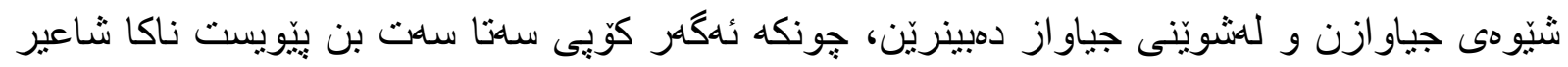

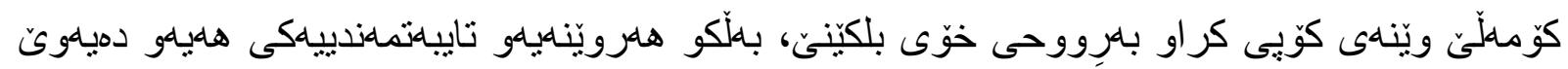




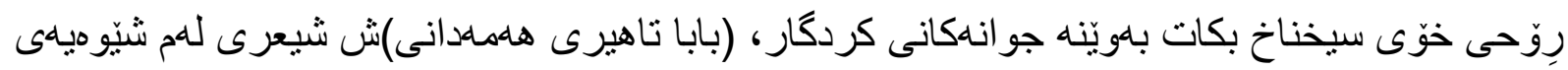

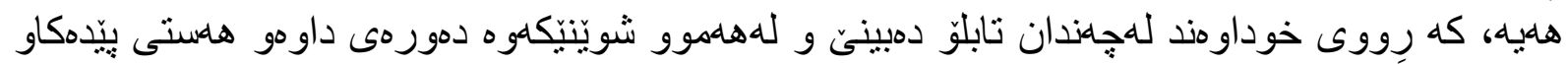

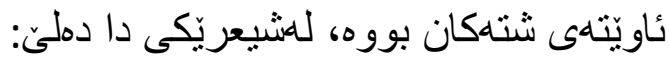
بامدريا بنكرم دمريا نو وينم باسهر ا بنكرم ساحر ا توينم باههل جا بنكرم كوّهو دمر و دمشت

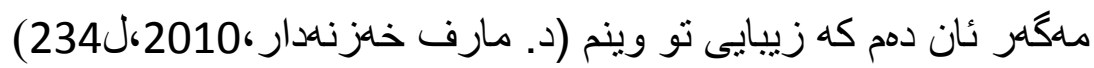

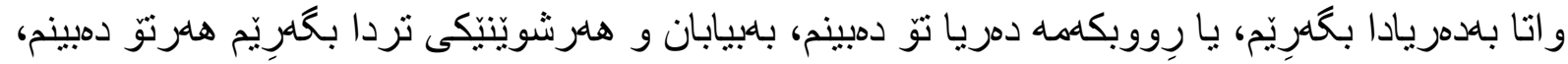

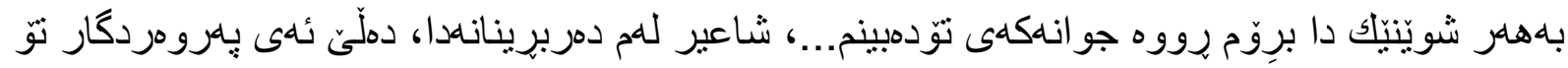

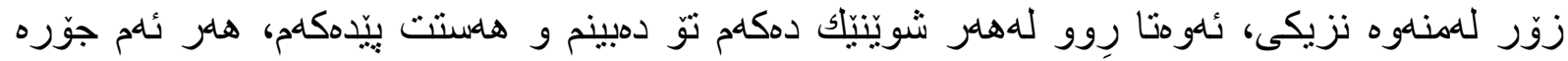

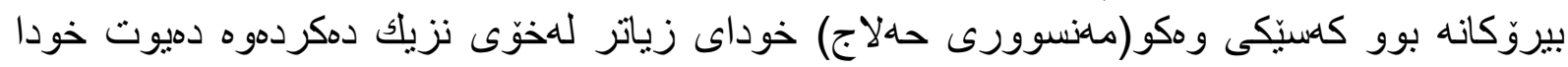

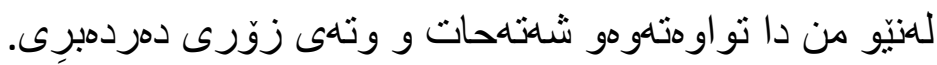

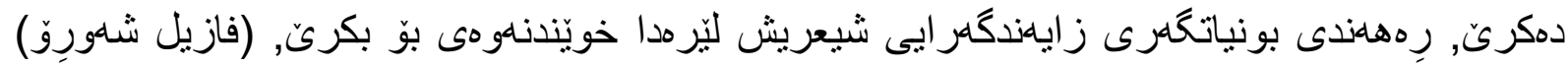

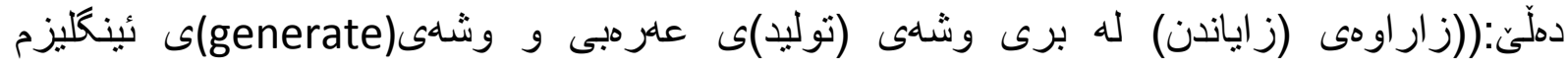

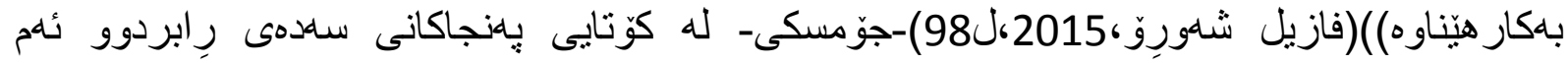

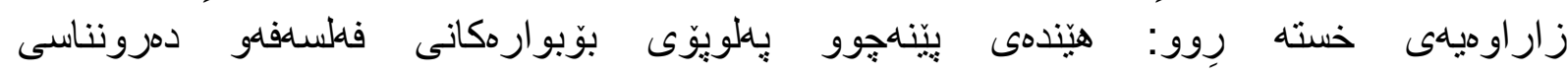

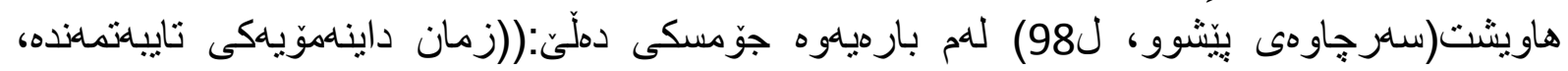

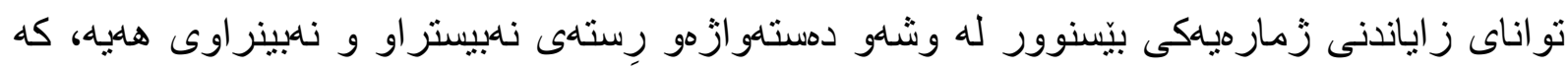

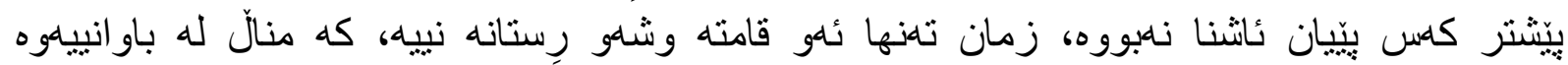

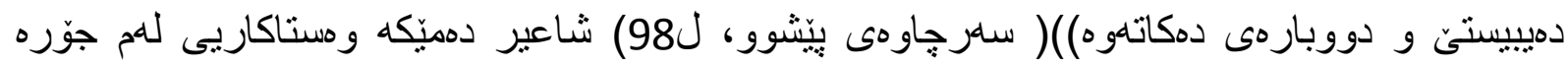

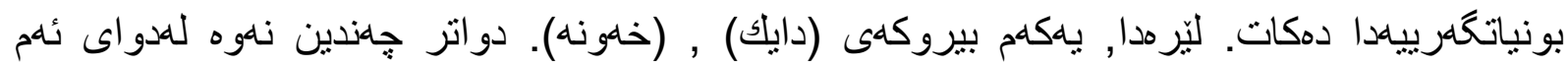

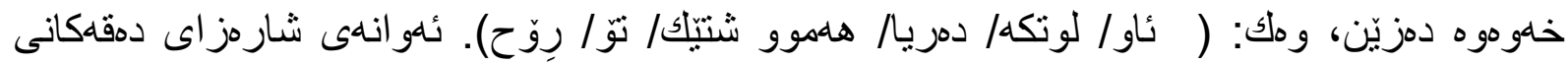

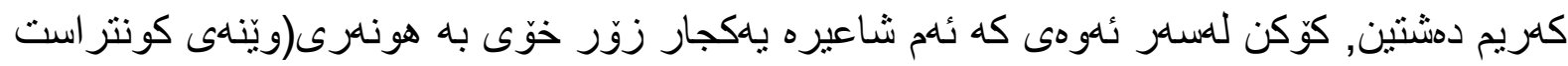
Contrast Images (

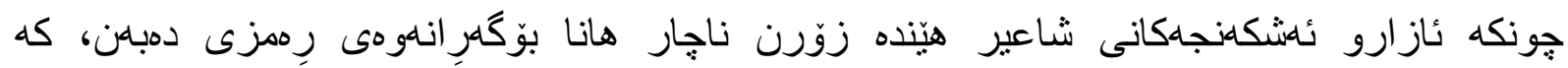

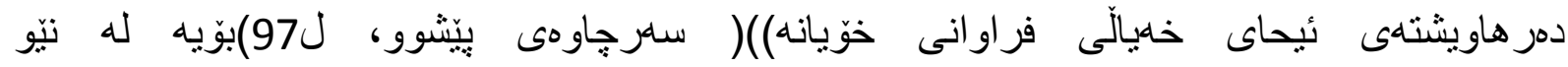

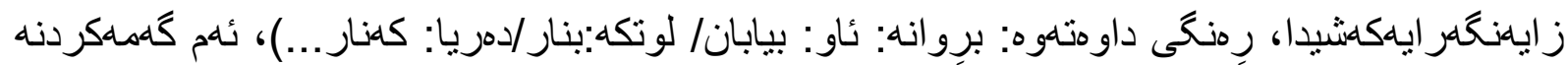

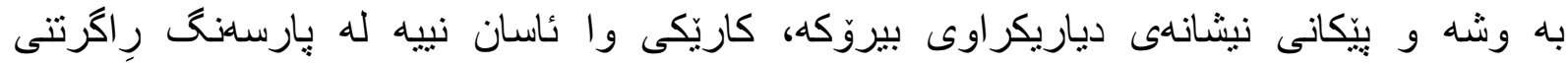

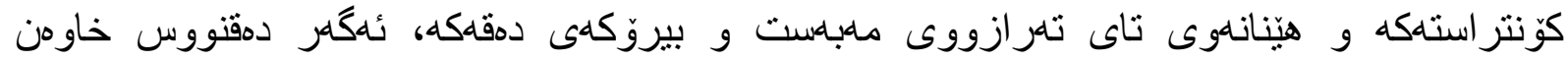

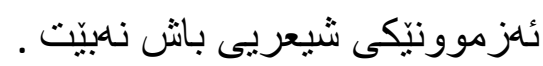

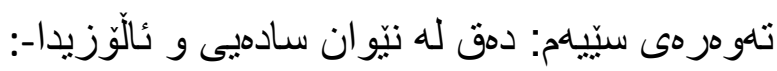




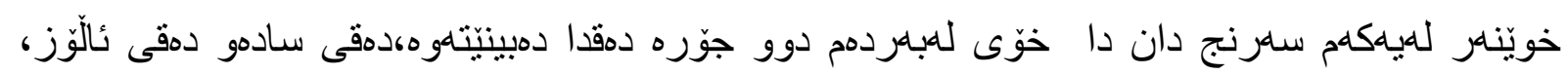

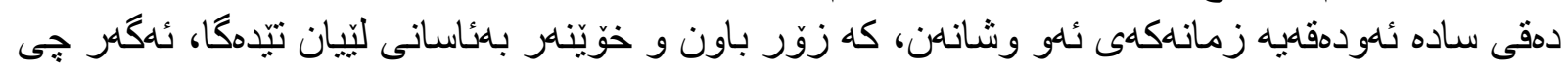

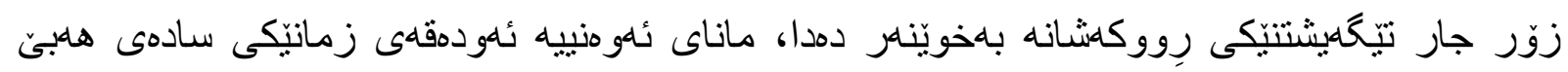

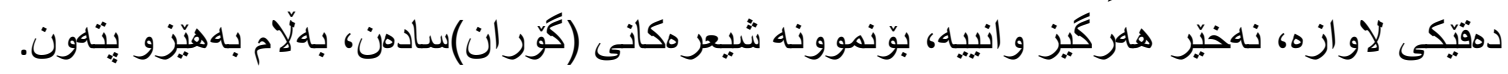

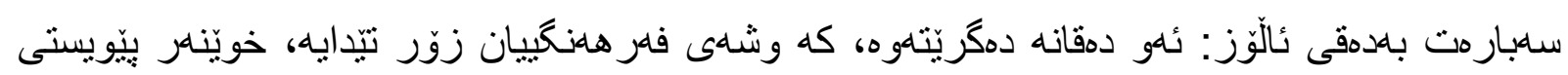

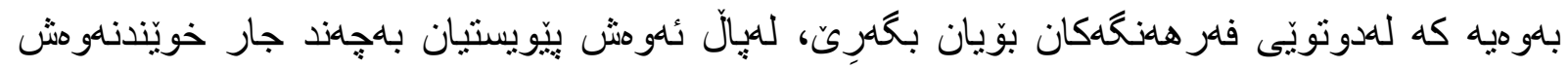

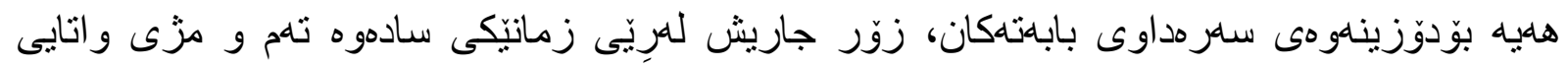

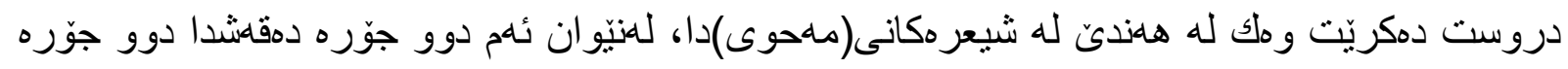

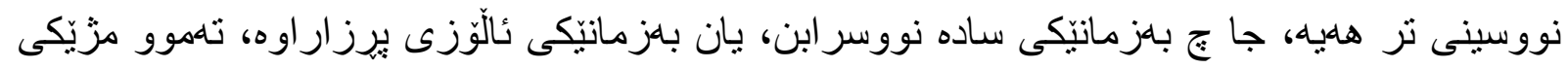

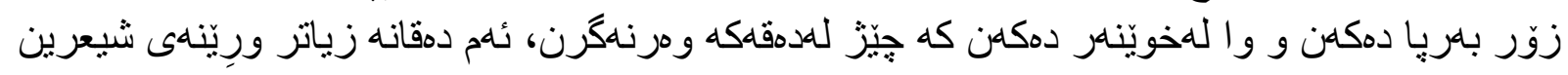

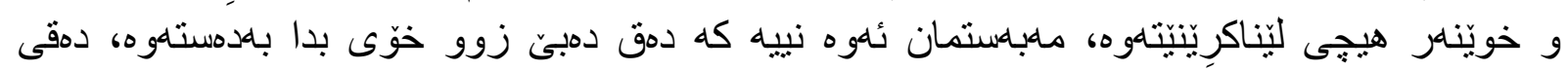

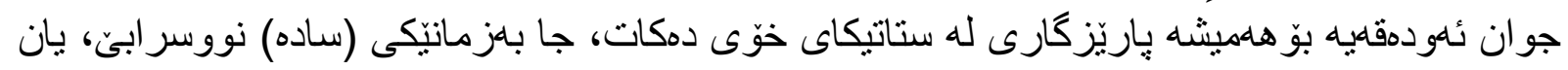

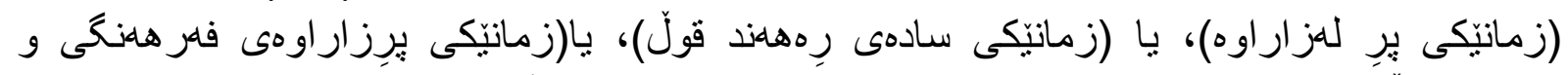

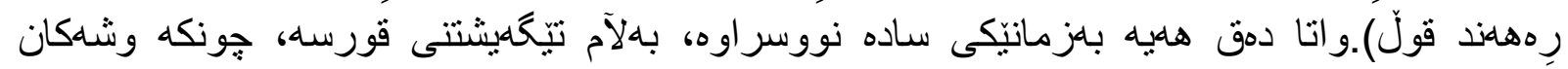

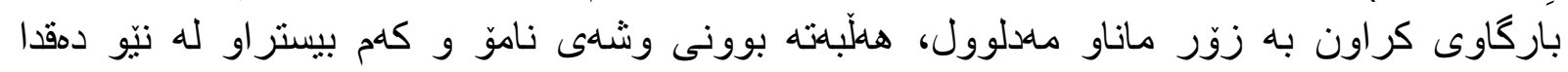

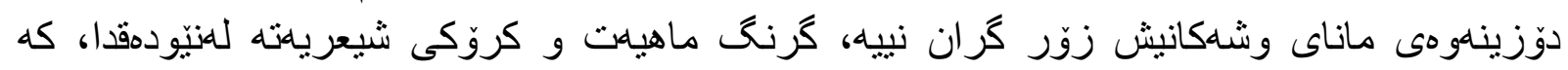

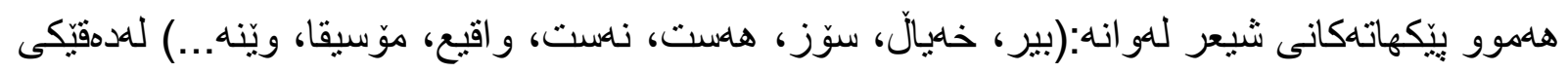

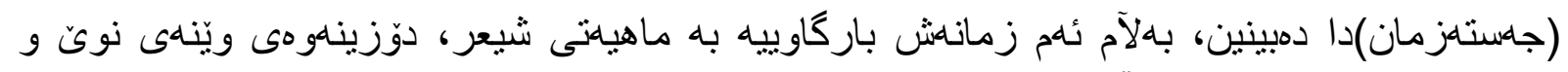

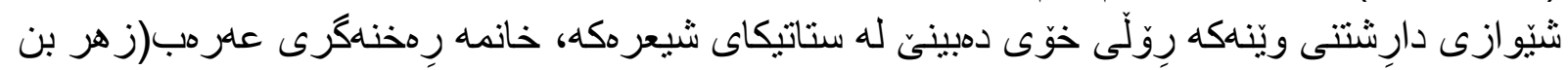

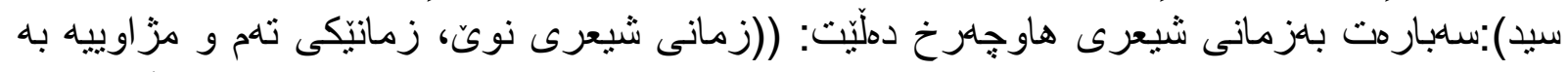

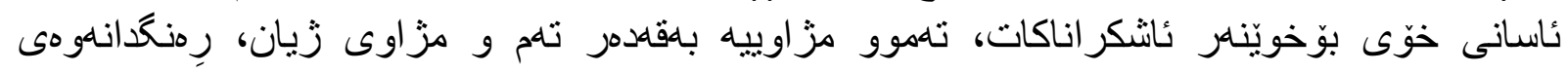

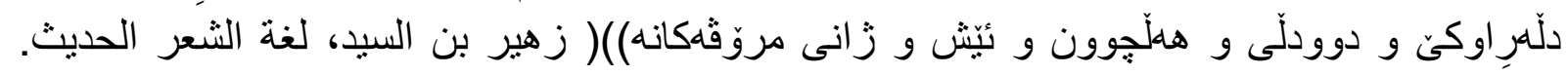

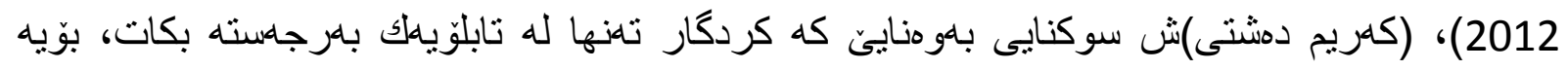

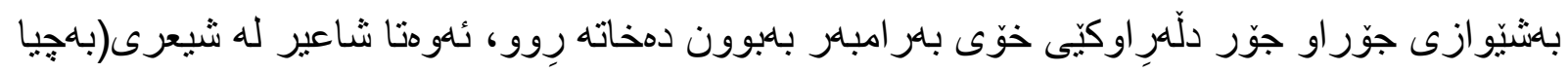

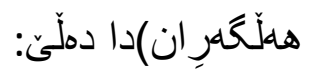

كه بانكت دمكهم هينّد دوورى ئاو هكان وهلآم دمدهنهوه كهبانكت دهكةم هينّد دوورى دارستانهكان وهلآم دمدهنهوه بوّيه سارسامم ناز انم

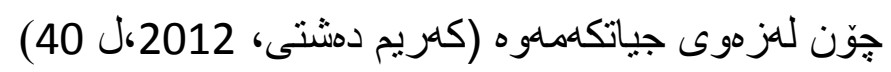

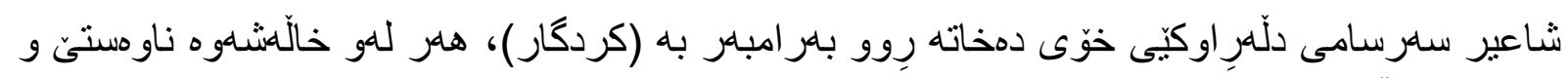

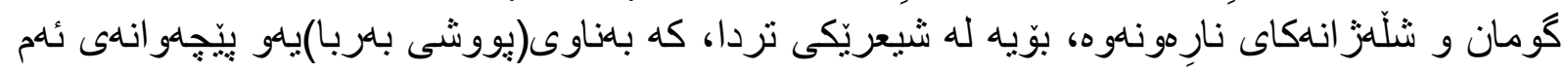
شيعر هيهو دملّيّ:

بيّ توّ من هلهبوونم نييه بيّ توّ من جيم 
توّ هاميشَه للنتهماهو لهناو للهيى دهستهكانمى للهناو كليّنهى خويّنمى

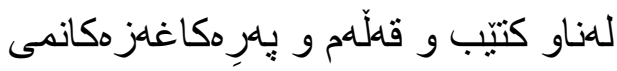
لنهاو سيّبهرو سايهمى بوّيه هلركيز من تلفها نيم(سهرجاوهى يِّيشوو، ل72) لله دهقهياندا خودا زياتر للهخوى نزيك دهكاتهوهو وهك (مهنسوورى حهلاج)ئاويتّهى رِوّح و كِيان و

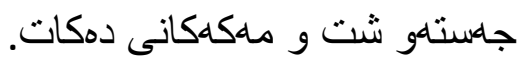

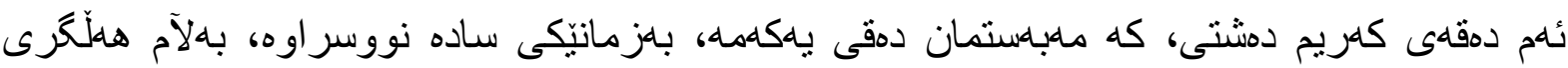

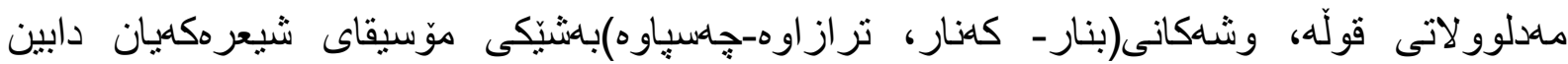

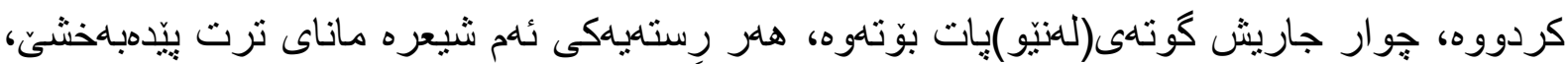

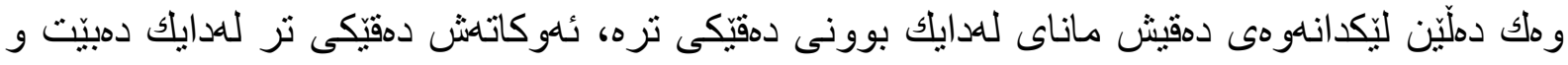

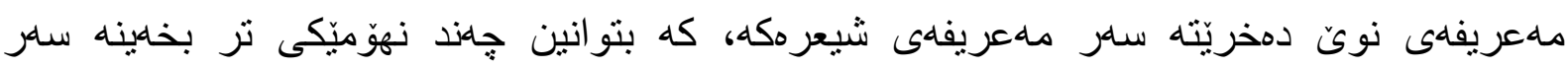

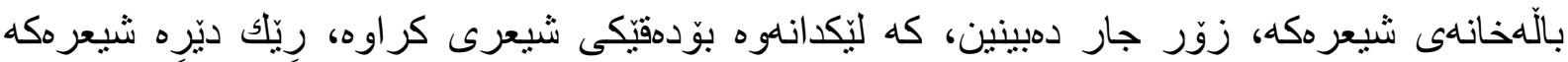

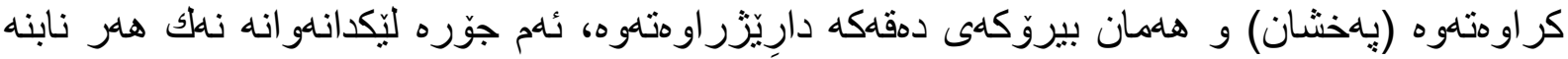

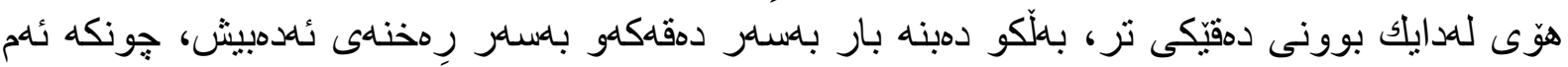

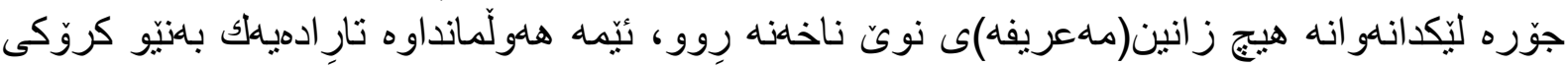

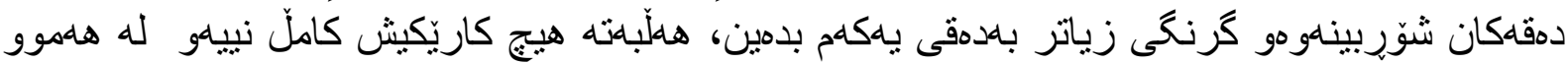

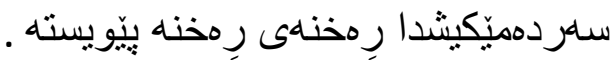

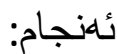

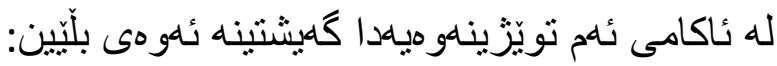

*كهريم دهشتى خاوهن جيهانبينييهكى تايبهته بوّ بون و كهون، شيعرهكانى رههانديّكى فكرى و فهلسهفى له خوّ دمكرن.

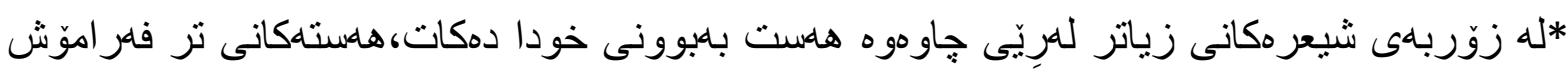

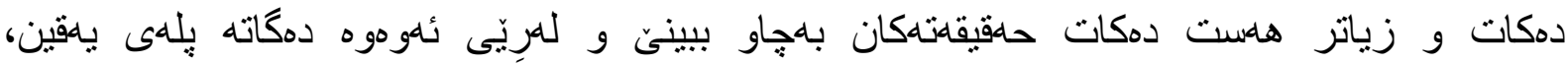

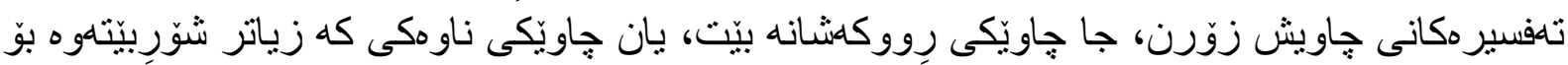
زهين و هلمست و شعوور 


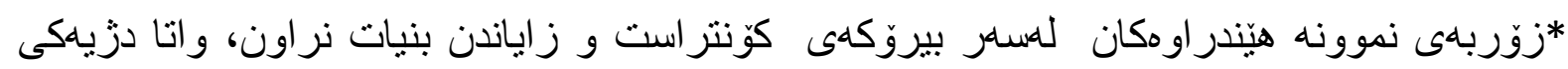

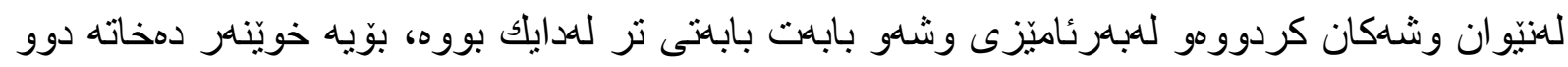
جوّره بكر اورددوه ه.

\section{كورتنى باس}

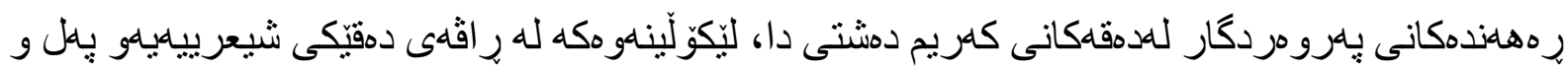

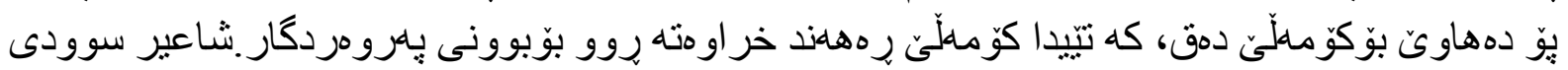

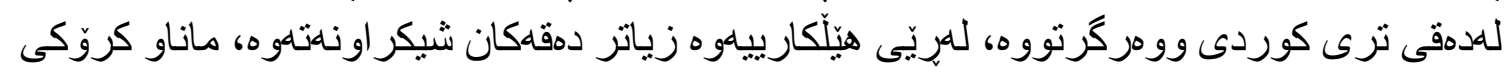

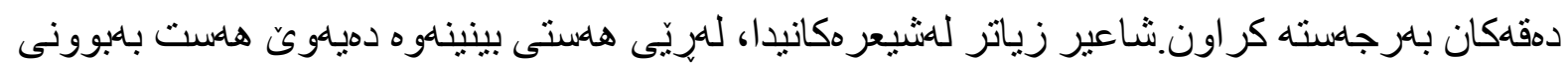

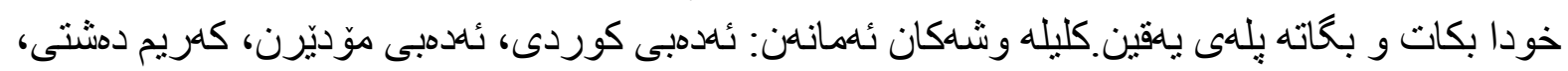

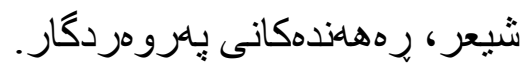

\section{ملخص البحث}

هذا الموضوع بعنوان(ابعاد الخالق)في اشعار الثاعر(كريم دشتى)، وسبب اختبار هذا الموضوع يعودُ لُّن الى ان النصوص تحنوى على هذه الابعاد.

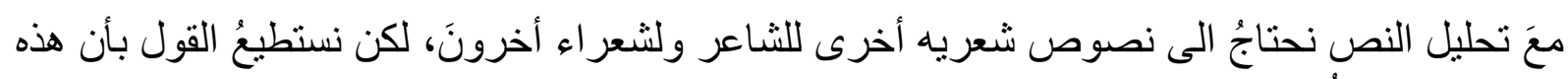

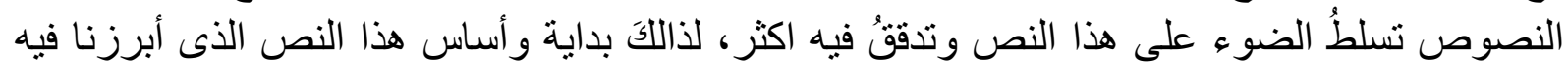
روئيه الثشاعر.

بعد تحليل النصوص و التخطيط لها أظهرنا الثعر ، بعد ذللكَ نتكلّم عن ستاتيكا هذا النص ونتكلم عن النصوص الثعرية بينَ المعقدة و البسيطة. 


$$
\begin{aligned}
& \text { سلرجاوهكان: } \\
& \text { كتاب مقدس/ قرأن كريم } \\
& \text { كتيب:- }
\end{aligned}
$$

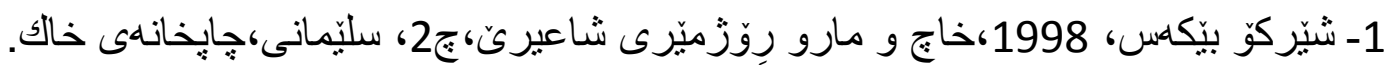
2-فاروق رِهفيق، 2010، هو نهرى عيشق ب1، سليّمانى،جإيخانهى ساردمد.

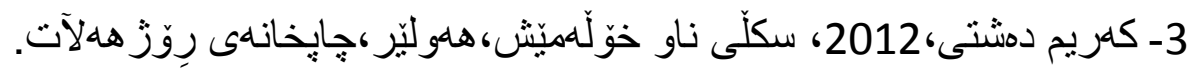

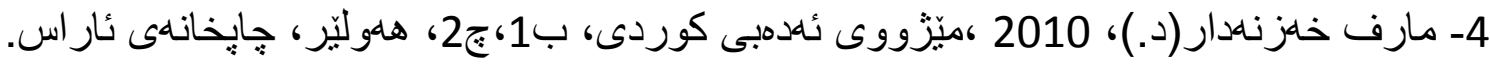

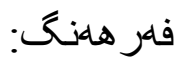
- مهلزًار،1384، هلنبانه بوّرينه، جايى جو اره،تهر ان،سوش.

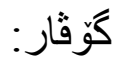

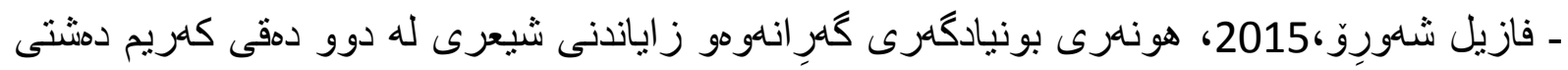

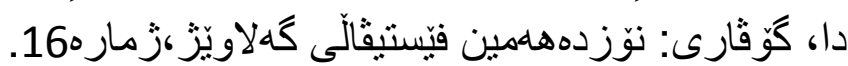

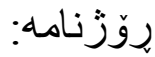

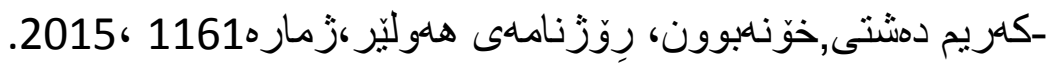

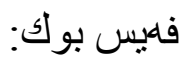

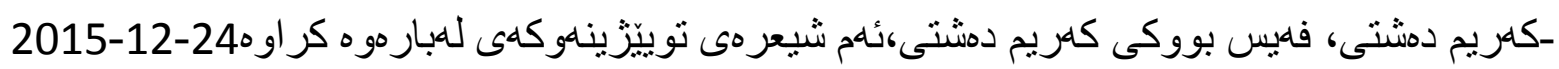

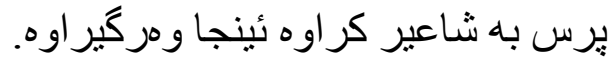

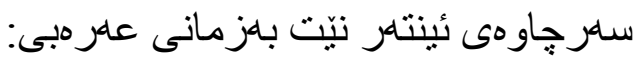
-ز هير بن السيد،2012, لغه الثنعر الحديث..، almol3/vb/shawthread.php له 2015-12-12 وهركير اوه. 